\title{
Femoral implant screwed on the lateral femoral shaft
}

Yves cirotteau*

Neuilly Sur Seine Hospital, Courbevoie, France

The Philosophy of this implant is to respect as much as it is technically possible the bone physiology. The surgical theorical concept is based on three parameters: The respect of the upper femoral metaphysis elasticity. The periosteum property. The respect of the medullary stem canal [1]. The cancellous bone of both long bone's extremities is the most important element of their elasticity and needs compression [2]. The periosteum is acting during all day life. It produces bone apposition even when or/and over 100 years [4]. The medullary canal vascularised $2 / 3$ of the femoral shaft cortex [2], provides blood cells and interferes in bone's remodelling [5]. At last the femoral component must reproduce the compression strain acting on the medial part of the femoral upper metaphysis in order to avoid resorption of the calcar [6-7]. For these biological facts, it is important to use them or to minimise either their destruction or their removal. The principle is to remove the least possible cancellous bone in the upper femoral metaphysis, to use the perisoteum bone apposition and do not enter in the medullary canal.

Figure 1 shows as the first femoral component was in Chrome Cobalt alloy. (Vitallium). The second is in Titanium. The femoral component is screwed on the lateral femoral shaft. The screw diameter is $5 \mathrm{mms}$ (c) to fix the plate on the femoral shaft and $7 \mathrm{mms}$ (a) to maintain the greater trochanter. Two teeths (b) prevent gluteus medius muscular action. The hole's plate and screw's design are according to the Meyrues and Cazenave's experimental work [8].

Eccentricity of the right metallic femoral head $0.7 \mathrm{~cm}$ loosening of polyethylene in 30 Years No calcar resorption, no screws fracture, periosteum inamovible apposition. Harris score: 100 (Figures 2-14).
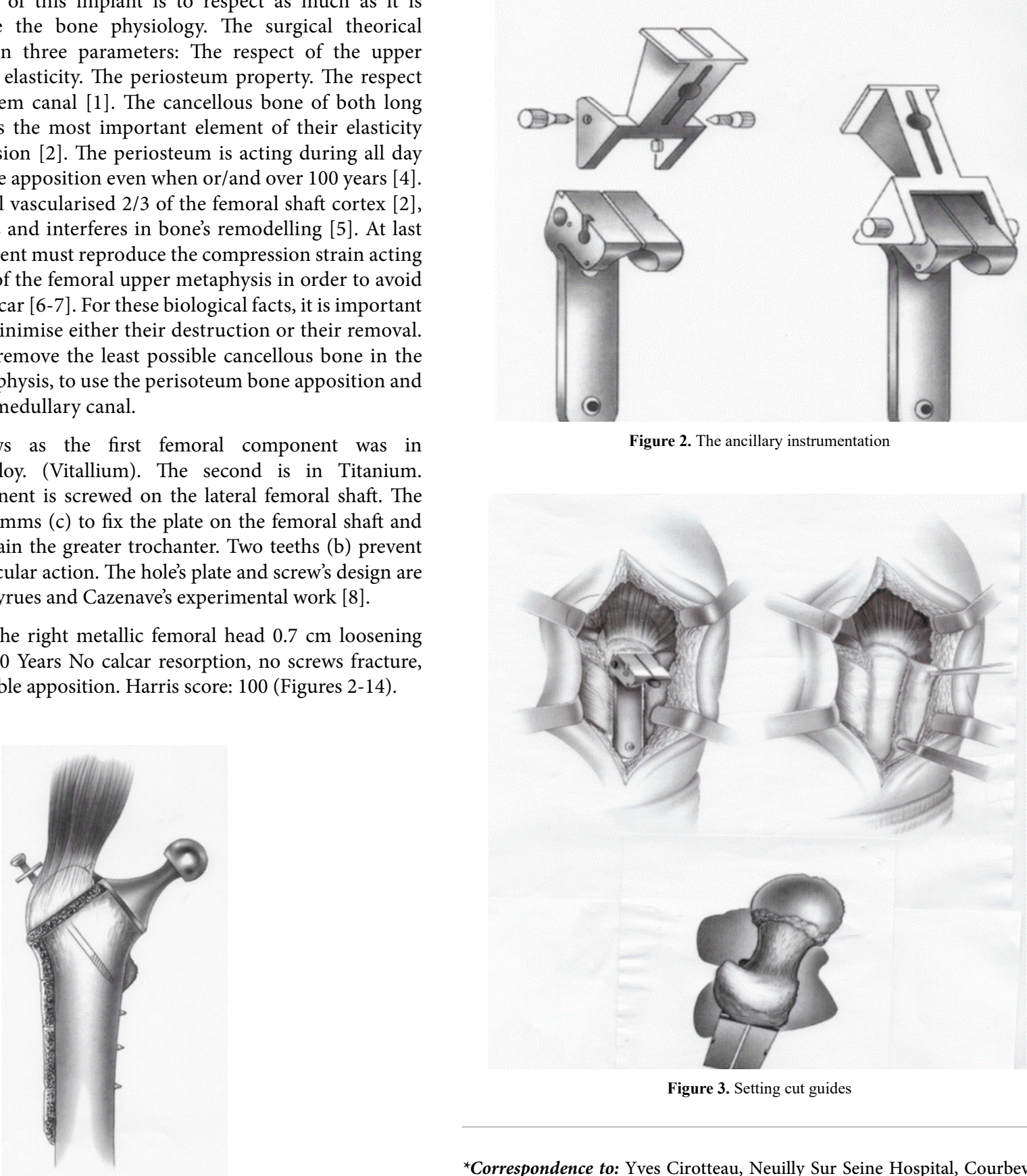

Figure 2. The ancillary instrumentation

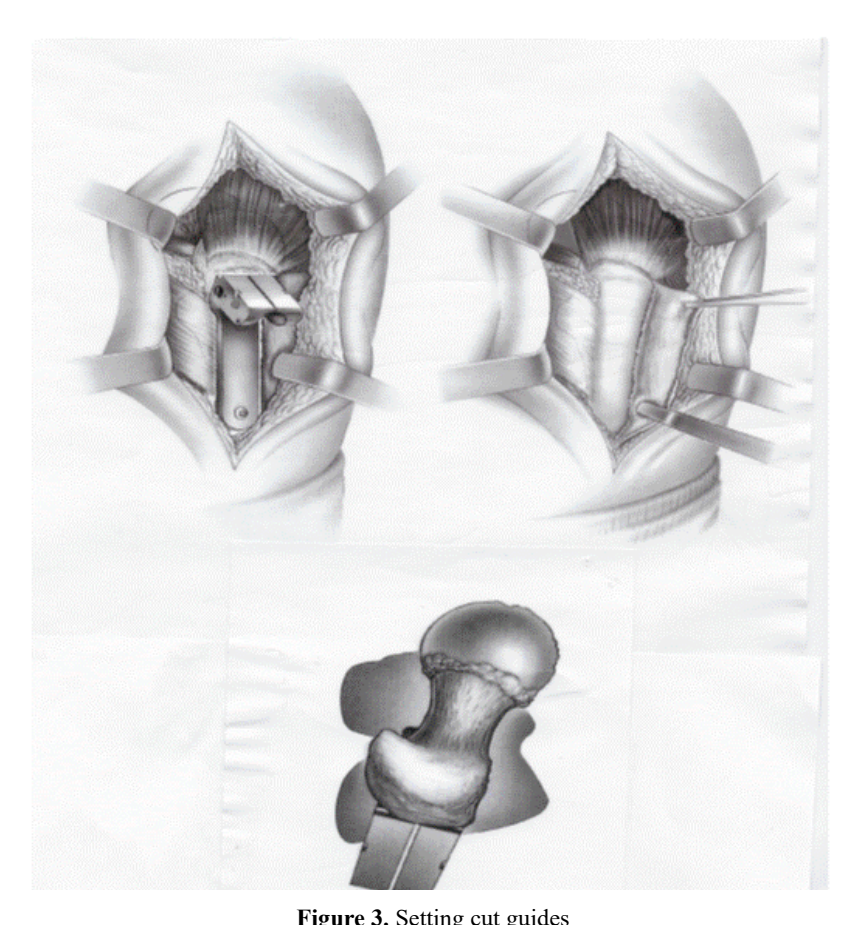

Figure 3. Setting cut guides

Figure 1. Female implant with external cortical support

${ }^{\star}$ Correspondence to: Yves Cirotteau, Neuilly Sur Seine Hospital, Courbevoie, France, Tel: 33O621888265, E-mail: ciroto@club-internet.fr

Received: April 19, 2019; Accepted: May 20, 2019; Published: May 27, 2019 


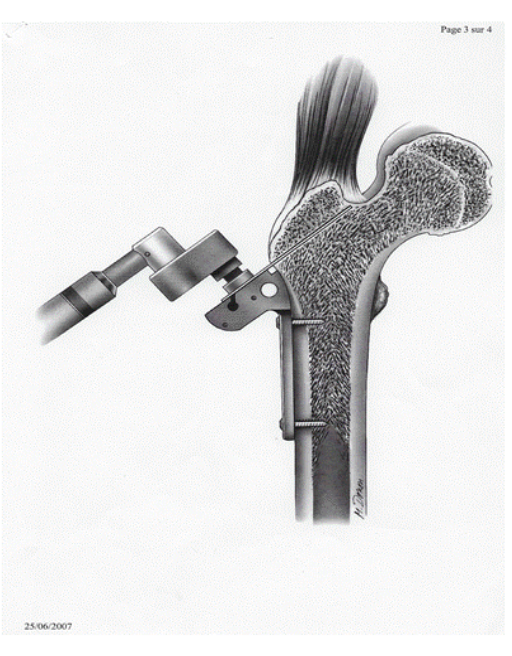

Figure 4. Greater trochanteric cut

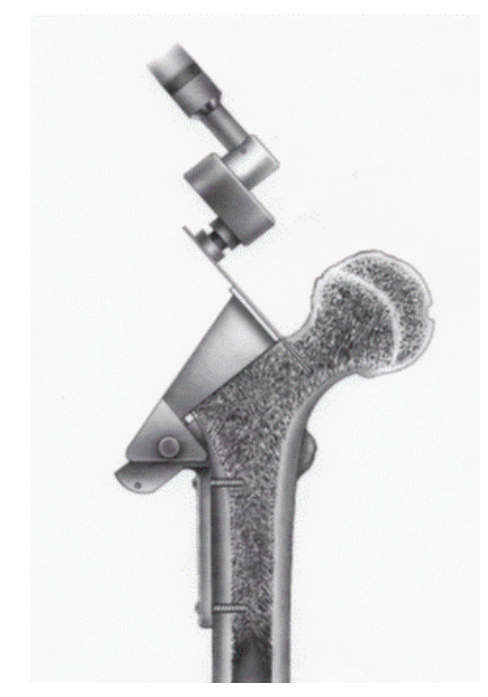

Figure 5. Femoral neck section

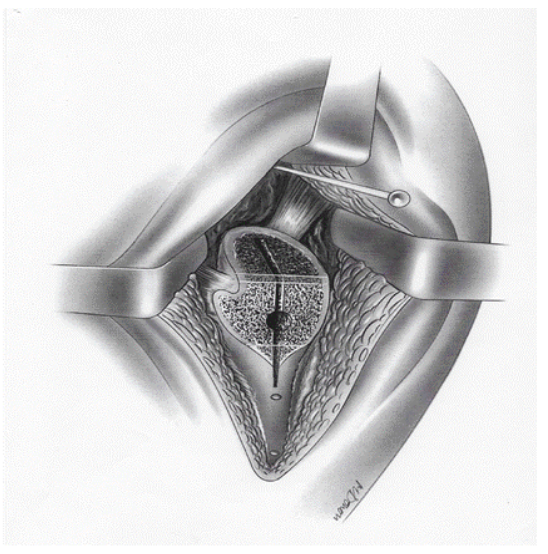

Figure 6. Aerial view of both sections

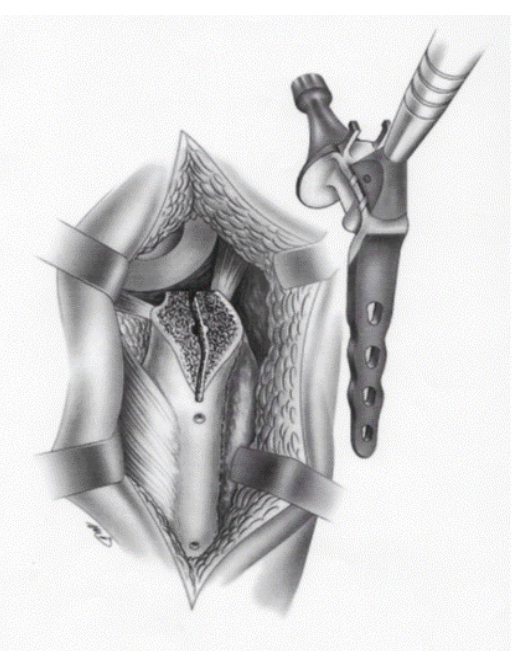

Figure 7. Positioning of the implant

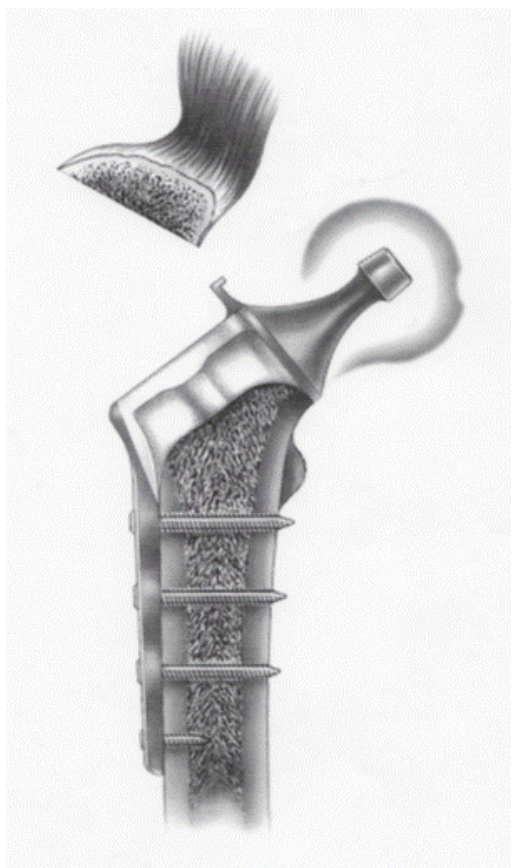

Figure 8. Screwing of the femoral implant

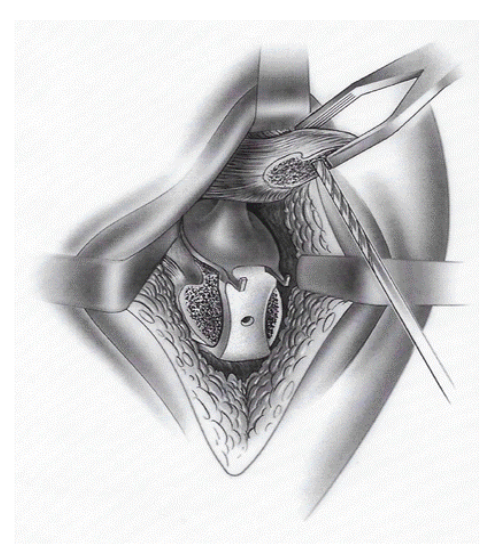

Figure 9. Preparation of the trochanteric screw 


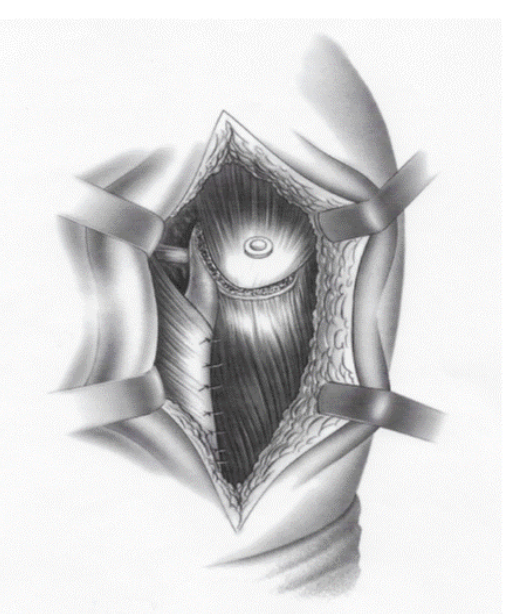

Figure 10. Greater trochanter in place

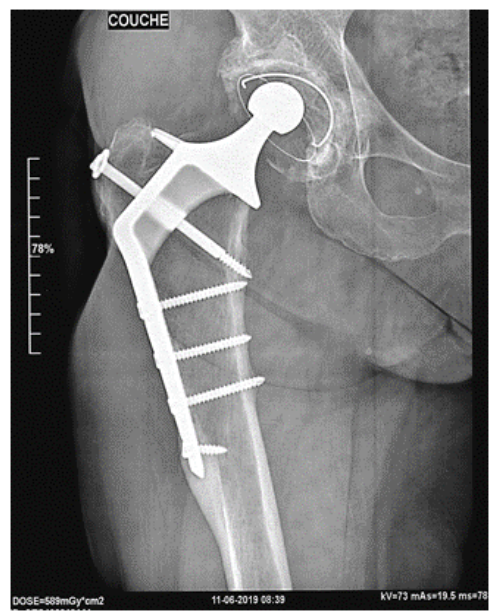

Figure 11. Thirty years after surgery

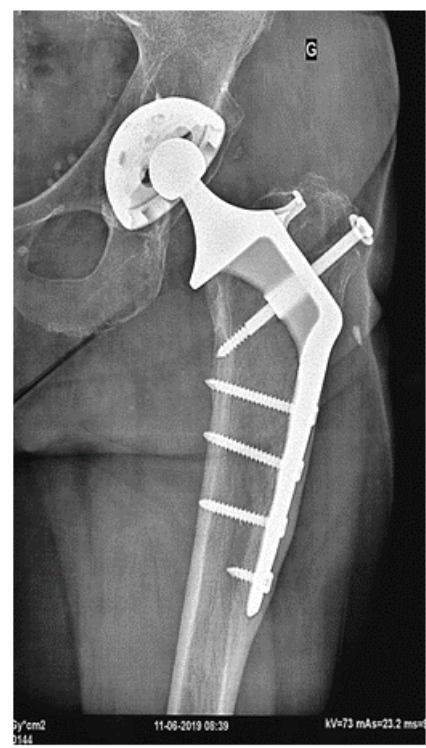

Figure 12. Twenty-six years after surgery
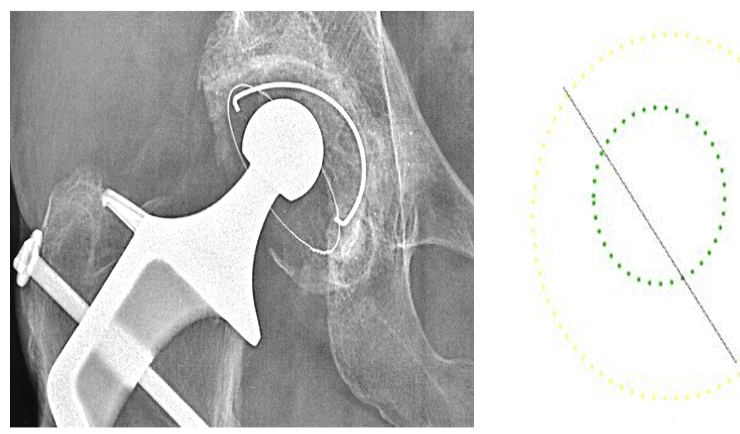

Figure 13. 30 years follow up excentration of the head: $0.7 \mathrm{~cm}$ and $\neq 0.02 \mathrm{~mm}$ per year
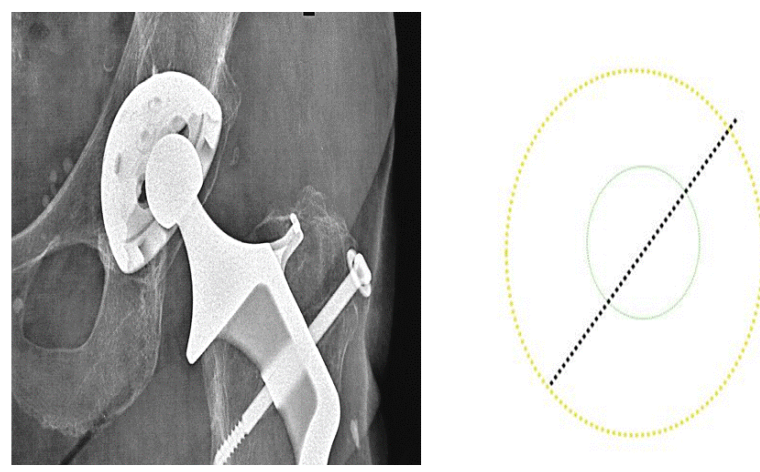

Figure 14. Polyethylene loosening 26 Years follow-up and $\neq 0.015 \mathrm{mms}$ per year $(0.015 \times 26=0.39)$

\section{References}

1. Modifications morphologiques de la métaphyse fémorale supérieure chez l'homme atteint de la maladie ostéoporotique. Y. Cirotteau; Académie des Sciences. Mai 1999, III.

2. Vico L, Collet P, Guignandon A, Lafage-Proust M-H, Thomas T, Rehailia M, Alexandre $\mathrm{C}$ (2000) Effects of long-term microgravity exposure on cancellous and cortical weightbearing bones of cosmonauts. THE LANCET 355.

3. Teot L, Vidal J, Dossa J (1989) Le tissu osseux; Sauramps Medical, Montpellier.

4. Kibbin MB (1978) The biology of fracture healings in long bones. $J$ Bone and Joint Surg 60B: 150-161.

5. Anne Devulder. Approche micro-mécanique du remodelage osseux. Ecole Centrale Paris, Thèse: 2009. NNT: 2009ECAP0020

6. Dumbleton J. Bushelow M (1990) A strain gauge analysis of the Cirotteau's hip prosthesis. Avril1990

7. Pelisse J (1990) Étude sur plateau de marche de la prothèse de Y. Cirotteau. CRA.

8. Etude théorique et physique expérimentale des contraintes dans les vis d'ostéosynthèse: Meyrueis JP, Bonnet, de Bazelaire, Zimmerman R, Cazenave A, Couve A. Rev. chir. orthop. 1979, Suppl.II, 65.

Copyright: (C2019 Cirotteau Y. This is an open-access article distributed under the terms of the Creative Commons Attribution License, which permits unrestricted use, distribution, and reproduction in any medium, provided the original author and source are credited. 